DOI: doi.org/10.21009/IJLECR.072.20

Received: 14 December 2021

Revised: 16 December 2021

Accepted: 16 December 2021

Published: 31 December 2021

\title{
SLANG LANGUAGE AS REPRESENTATIVES OF SOCIAL CULTURE IDENTITY IN FILM STEP UP 2 THE STREETS
}

\author{
Sufi Alawiyah ${ }^{1, a)}$, Zuriyati ${ }^{2, b)}$, Ninuk Lustyantie ${ }^{2 . c)}$ \\ Universitas Bina Sarana Informatika, Indonesia ${ }^{1)}$ \\ Universitas Negeri Jakarta, Indonesia ${ }^{2)}$
}

sufi.sfy@ bsi.ac.id ${ }^{\text {a) }}$,zuriyati@unj.ac.id ${ }^{\text {b) }}$,ninuk.lustyantie@unj.ac.id ${ }^{\text {c) }}$

\begin{abstract}
Slang is an innovation of language change created by a group of people in highlighting their group. Speakers build a cohesive identity and a separate social class that becomes a culture in society. The purpose of this study was to gain an in-depth understanding of slang as a manifestation of a person's social-cultural identity in the community group in the film Step Up 2 The Street. The method used is descriptive qualitative. Data was collected using documentation. The data is in the form of utterances in the dialogue of film players that contain slang words. Data analysis through the stages of data reduction, presentation and concluding. The results of the study conclude that the use of slang in the film Step Up 2 The Street shows the diversity of social and cultural identities in people's lives. The group of slang users refers to the context of similarity in the race, kinship or group, level of intimacy, group localization, and social culture that characterizes each group. It gave an impact on comprehending the framework of cultural identity.
\end{abstract}

Keywords: Culture, Identity, Language, Social, Slang

The concept of 'slang' refers to the commonly known linguistic variation among peers of the same standard and social status. Slang is typical of the spoken and informal side of human interaction, and slang words are limited in their social status, culture and geographical distribution. These words are used as symbols of subculture membership (while excluding non-members) and reflect the spirit of creativity, fun and fashion. Although slang is considered a viable sociolinguistic phenomenon, several neologistic formations draw attention to their idiosyncratic existence. Changes in human life so far have also affected the use of new and innovative languages in a striking way that can affect the linguistics of the language itself. For example, the Semi-Arab Muslim Revolution has given birth to language innovations that have an impact on the transformation of the masses and the structure of Egyptian society. The ideological stance of linguistic choice has been interpreted in the context of Egyptian culture and the various factors that have emerged in the dominating phenomenon. In many aspects, the slang expressions of young people in Egyptian society are composing words and expressions that depend on their social and cultural needs. Egyptian society mostly meets the wishes of the young with refusal. The non-acceptance of slang by other social groups makes young people more assertive to use such abnormal language usage.

In the social aspect, usually, the use of slang in a community or region is equal to the level of formality of speakers and listeners to build a close relationship or not to be ignored by others. One of the media that can be used in understanding slang is the film because the film is a literary work 
that has many influences on human life and changes that can occur in the use of language. Often the film is presented as a form of representation of real human life. In addition, films are also multimodal texts that represent the use of language through interesting text and visual forms. Many uses of language in films are interesting to study more deeply and are related to current conditions as part of the factors that influence the model of human life. Moreover, language also reflects as a social reality and a means of communication that continues to develop and undergo transformation. This means that it can continue to adapt to change and self-representation or a means to dominate others. It cannot be denied that the multiplicity of social groups in a given community is reflected and reflected through the linguistic choices of the members of these groups. It is the context of the situation in a particular society that governs the way language is used. One of them is the use of slang in social groups as represented in the film Step Up 2

The Step Up 2 The Streets movie, this film was released on July 15, 2008. This film tells about the street dancer community in America. The community members are teenagers who often use slang as the brand's spoken language. So, this research is related to the analysis of slang in films as a form of understanding the representation of social-cultural identity for people's lives. This research is important to do for several reasons; 1) there is still little research on slang through the concept of social-cultural identity. This means that slang is part of the implementation of literary works for the social life of society. 2) To place slang in a society frame that reflects every social class. 3) Slang is offered as a major index and a signal of alienation and solidarity, which is remarkable because the same elocutionary can signal both of them in the same situation. 4) The study of slang can contribute substantially as an important component of linguistic and social behaviour so that it is methodologically used as the basis for integrating the study of language and society, as well as literature in a unified theoretical framework. Thus, this research is related to slang in the film Step Up 2 The Streets as a form of understanding social culture identity. So, this research is related to the social relationship of the level of slang users.

Many previous studies have examined the use of slang in films. Slang is usually used in informal situations and certain social classes. The use of slang related to social factors emerges from the understanding of the participants' position, background, topic, and function factors while the social dimension influences it in the social distance scale, status scale, formality scale, and two functional scales (Meinawati, 2017). In the study of novels, slang shows solidarity and intimacy between characters which interprets equal status in social status, higher status positions than lowerstatus positions (Nasution et al., 2021). In song lyrics, some authors wrote the lyrics that are relevant to the situation today through slang language (Hidayat \& Mu'man, 2020). In every language in this world, there are changes and new language innovations that appear as part of the identity of a particular group so that the creation of slang can also be understood not only in the form of new words but expansion through the addition of insertions, suffixes or prefixes in words (Kudirka, 2021). As in Ukrainian, which is undergoing rapid change, many words become archaic, but new artefacts emerge (Sergienko, 2018). In addition, slang is often used for communication in social media groups such as WhatsApp (Budiana \& Setiyoko, 2021). Currently, the emergence of slang in young people's conversations is very high, especially when viewed through interactions on social media such as Facebook, Instagram and Youtube. Social media users, especially the younger generation, are very creative and active in forming new slang words (Budiasa et al., 2021). The analysis of slang translation in the film also shows that different slang translations in the translation are caused by cultural differences from different slang speakers (Istiqomah et al., 2019).

The advantage of the research that has been done lies in the emergence of language changes or innovations through slang used for communication between groups. However, this research has not touched on the sociological aspect of slang itself. Slang is an ever-changing collection of 
everyday words and phrases that speakers use to establish or strengthen social identity or cohesiveness within a group or with trends or fashions in society in general. From this assumption, this study shows different concepts through the study of related literary works from the use of slang as a manifestation of the cultural differences of language users and social representation of society. A sociolinguistic study of slang as a unique style of speech. Moreover, the level of public acceptance of the slang used is also different, and the spread of such linguistics offers various opportunities for marginalized social groups to express their novelty and uniqueness. This is an interesting phenomenon in understanding the level between the speaker and the listener. In addition, this study can show a person's identity status from the slang language used by each actor in the film Step Up 2 The Streets as a real example for the relevance of the phenomenon of slang language that is often used by young people today on social media. This uniqueness and novelty offer readers that language is always evolving and changing, innovating from the form of culture and identity of community groups who want to strengthen their social status.

So, the purpose of this study is to identify the use of slang in the film Step Up 2 The Street to represent the social-cultural identity of community groups. This research is expected to make a real contribution to understanding the concept between language variations, social, literary works and also changes in language that follow changes in human life.

\section{METHOD}

This study uses a qualitative approach through qualitative descriptive methods. Qualitative research with an inductive approach is used by making observations at the beginning to describe a phenomenon being studied, and an open-ended approach using open-ended questions to seek an indepth description and interpretation of the researcher's experience. In addition, qualitative inquiry focuses on processes that produce understanding rather than outcomes (Maxwell, 2013). This study explores the phenomenon of slang used in films that are relevant to social life. The data was collected in several steps: First, the writer watched the film several times to understand the whole story. Second, the writer identifies words and phrases that contain slang. Third, the writer marks and collects the data into a table. Fourth, the writer classifies the types of slang terms found in the film. Finally, the slang words found are described in descriptive form.

The data is taken from the speech of the characters in the slang-language film and the source of the data is the film Step Up 2 The Street. While the method used to collect data in this study is through documentation. The data analysis technique consists of data reduction, data presentation and conclusion drawing.

\section{RESULTS AND DISCUSSION}

The result of classification data, slang language in this movie is the below: Table 1. Slang Words That Represented as Social Culture Identity in Film Step Up 2 The Street

\begin{tabular}{|l|l|l|l|}
\hline No & \multicolumn{1}{|c|}{ Slang } & \multicolumn{1}{|c|}{ Meaning in Dictionary } & Social Culture Identity \\
\hline 1 & Son & Closest friend & $\begin{array}{l}\text { Group-Restriction, Social class and } \\
\text { status in the same group }\end{array}$ \\
\hline 2 & Spot & $\begin{array}{l}\text { An apartment or house } \\
\text { US, 2001 }\end{array}$ & $\begin{array}{l}\text { Secrecy, language in the same social } \\
\text { class }\end{array}$ \\
\hline 3 & Aye & $\begin{array}{l}\text { Yes, Scootish way of } \\
\text { saying yes }\end{array}$ & Hybridism \\
\hline 4 & Gotcha & Igot you & Desire to impress \\
\hline
\end{tabular}




\begin{tabular}{|c|c|c|c|}
\hline 5 & Ain't & $\begin{array}{l}\text { Replaces am not, are not, } \\
\text { is not, has not, have not. }\end{array}$ & Efficiency \\
\hline 6 & What's up & Hi/Hello & Color \\
\hline 7 & Bouncing & To leave & Color \\
\hline 8 & Big deal & $\begin{array}{l}\text { Anything very important; } \\
\text { consequential event or } \\
\text { circumstance Often used ironically } \\
\text { to deflate someone }\end{array}$ & Informality \\
\hline & & 2. An important person; & \\
\hline 9 & $\begin{array}{l}\text { What's } \\
\text { poppin }\end{array}$ & 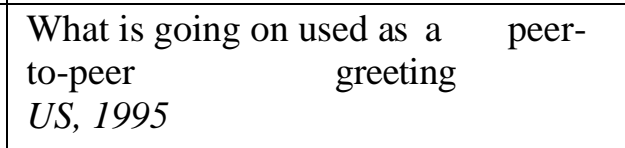 & Color \\
\hline 10 & Benjamin & A one hundred dollar bill. & Unconventionality \\
\hline 11 & Baby & $\begin{array}{l}\text { Used as a friendly term of } \\
\text { address } U S\end{array}$ & Group-Restriction \\
\hline 12 & Yo & $\begin{array}{l}\text { Used as a greeting. Both Italian- } \\
\text { American andblack communities lay } \\
\text { claim to } \\
\text { 'yo! }\end{array}$ & Orality \\
\hline 13 & Running off & To have diarrhea & Color \\
\hline 14 & Whatever & $\begin{array}{l}\text { I don't care; it doesn't } \\
\text { matter which choice; whatever } \\
\text { you want }\end{array}$ & Informality \\
\hline 15 & $\begin{array}{l}\text { Piece of } \\
\text { cake }\end{array}$ & Something very easy to do & Secrecy \\
\hline 16 & No way & $\begin{array}{l}\text { Used for expressing disbelief at that } \\
\text { which has } \\
\text { just been said } U S, 1968\end{array}$ & Orality \\
\hline 17 & $\begin{array}{l}\text { Freaked } \\
\text { (out) }\end{array}$ & Tired out & Color \\
\hline 18 & Rap & $\begin{array}{l}\text { To talk or chat about } \\
\text { something }\end{array}$ & Color \\
\hline 19 & Gig & $\begin{array}{l}\text { A live performance, either musical } \\
\text { theatrical, or } \\
\text { physical }\end{array}$ & Subject-Restriction \\
\hline 20 & Texting & $\begin{array}{l}\text { The act of sending a } \\
\text { message by cell phone }\end{array}$ & Efficiency \\
\hline 21 & Holer at & To talk over & Color \\
\hline
\end{tabular}




\begin{tabular}{|c|c|c|c|}
\hline 22 & Lockdown & $\begin{array}{l}\text { The act of someone controlling } \\
\text { somebody's social life and activities. } \\
\text { any situation in which your } \\
\text { complete freedom is restricted. }\end{array}$ & Color \\
\hline 23 & Gosh & $\begin{array}{l}\text { Used in expressions of } \\
\text { surprise, UK }\end{array}$ & Localism \\
\hline 24 & Cool & $\begin{array}{l}\text { Fashionable, attractive, } \\
\text { admired } U S, 1947\end{array}$ & Color \\
\hline 25 & Freestlye & $\begin{array}{l}\text { The term for a form of Hip Hop } \\
\text { dance that borrows from many styles } \\
\text { of dance in and outside of Hip Hop } \\
\text { and then } \\
\text { freestyle's it off the top of the head } \\
\text { with no routines. }\end{array}$ & Efficiency \\
\hline 26 & $\begin{array}{l}\text { What's the } \\
\text { deal }\end{array}$ & What's going on & Color \\
\hline 27 & Messed up & $\begin{array}{l}\text { Describes a situation where someone } \\
\text { purposefully } \\
\text { something to complicate the life of } \\
\text { someone else }\end{array}$ & Color \\
\hline 28 & Kicked out & A dishonorable discharge & Color \\
\hline 29 & Old school & $\begin{array}{l}\text { A past generation with an old- } \\
\text { fashioned but reliable } \\
\text { way of doing things } U S \text {, }\end{array}$ & Efficiency \\
\hline 30 & Dopest & $\begin{array}{l}\text { Sickest; coolest; tightest; } \\
\text { most awesome }\end{array}$ & Color \\
\hline 31 & Homeboy & $\begin{array}{l}\text { Used to be a dislike, when calling } \\
\text { someone homely meant like a mama's } \\
\text { boy, } \\
\text { who never goes out. }\end{array}$ & Aggressiveness \\
\hline 32 & Homey & Closest friend & Group-Restriction \\
\hline 33 & Fish & A stupid and inept person & Offensive \\
\hline 34 & Guys /Man & $\begin{array}{l}\text { A man or a boy; a general form of } \\
\text { address; in the plural, it can be used of } \\
\text { and to men, women or a } \\
\text { mixed grouping }\end{array}$ & Group-Restriction \\
\hline 35 & Hold up & Wait a minute & Color \\
\hline 36 & Power trip & $\begin{array}{l}\text { Any activity that is motivated } \\
\text { by a desire for } \\
\text { power }\end{array}$ & Color \\
\hline
\end{tabular}




\begin{tabular}{|l|l|l|l|}
\hline 37 & Crib & $\begin{array}{l}\text { Home, domicile or } \\
\text { dwelling }\end{array}$ & Color \\
\hline 38 & Bro & Brother, friend & Group-Restriction \\
\hline 39 & Dang & $\begin{array}{l}\text { Softer version of "damn". Similar to } \\
\text { "darn". Used mostly by Southerners } \\
\text { and } \\
\text { Mormons }\end{array}$ & Localism \\
\hline 40 & Goodness & $\begin{array}{l}\text { To imply that something } \\
\text { is good, nice, tight }\end{array}$ & Orality \\
\hline 41 & Cheesy & $\begin{array}{l}\text { Not real } \\
\text { Short for Jesus, used by Christiana 2 } 2 \\
\text { friend UK, 2003.3 a look. A variant } \\
\text { of GEEK }\end{array}$ & Cocalism \\
\hline
\end{tabular}

Here is the example of analysis data for slang language as social culture identity in the film Step Up 2 The Street. It used some dialogue to support the slang words.

Data 1.

Missy : "Aye, why it gotta be me?"

Andie : "Cause you are the youngest"

Duration 00:04:46,319 --> 00:04:48,310

The slang word "Aye" is "hello". In this movie, it is used in communication between teenagers. It is a greeting when spoken to someone younger. Greetings in people's lives become a form of social culture that is usually done every time we meet. So, the slang 'Aye' in the context of this film shows the strata between older and deeper people using greetings.

Data 2.

Tuck : "Yo, the four-one-oh killed again, man." (Laughing)

Duration 00:04:20, 059 - 00:004:22,493

The word "Man" refers to the context of a male friend. It usually uses as someone's relationship with others in a group. In addition, the context in this film also identifies people of common age and has a shared experience. The word refers to the identity of a very close social relationship.

Data 3.

Felicia : "That was sick, son"

Andie : "Thank you very much I'm a genius"

Duration 00:04:22,562 --> 00:04:23,722

The word "Son" in the dialogue above indicates the identity of a close social relationship or family/relatives. This slang word is a form of expression in a conversation that occurs between groups where the status of the speaker has a higher position. In addition, this word is also usually spoken to fellow groups of the same race, colour or culture that exist in the same area because of the familiarity value possessed by the word.

Data 4.

Tuck : "Yo we got this gig at the dragon coming up"

All : (notice) 
The slang word "Gig", is not foreign. One of the reasons for using slang is to enrich the language and to be able to interact among members of a group. Each member must recognize the language, or they will lose the message. This word is a foreign term to outsiders, people from outside the group will not understand what the message is. This means that slang associates group members to receive and convey messages. And most of these memberships or groups distinguish and separate themselves from mainstream culture.

\section{Data 5.}

Man 1 : "Come on, man, we bouncing"

Man 2 : "We gotta go. You"re lagging"

Man 1 "'All right”

Duration 00:05:40,606 --> 00:05:42,631

Slang has many variants of the meaning of words or phrases available, it should be recognized by someone in social life to interact because many people who come from a certain area and cultural status will carry different language styles. By mastering the use of language, it will help someone to communicate with others.

Data 6.

Tyler : "Piece of cake"

Andie : "No way"

In addition to being able to speak in a group, slang is used as a language that cannot be understood by others. Sometimes group members hide their conversations by using unfamiliar words so that only members can recognize and receive messages. Like the term piece of cake, the two characters above are common if their conversation is known to others, it is marked as a secret between them. In this context, it is known that the social identity of the slang word refers to the status of group members who are related to each other who already know the customs and culture of the social group.

\section{Data 7.}

Tuck : "Hey yo DJ, Sand! Drop that beat homey? Looks like we got new fish in town."

Dj Sand : "Let"s clear the dance floor. See what they talking about"

Duration 00:45:48,612 --> 00:45:51,775

Homey means closest friend, this term is used among group members, one family, one race, and even share the same social culture, because this word indicates that they have a close relationship. Sometimes they have individual identity markers within a group to create intimacy and friendliness that is limited to them from the outside. For example, as found in the movie Step Up 2 The Streets, the D form is a nickname for one of the members of a group called four one oh. In the urban dictionary, the author finds the D form can refer to a person's first name, even though his name is Andie West, at least it is identified as familiarity and friendliness among group members.

Data 8.

Tuck : "Why don't you show us now, homeboy"

Kido : "All right let's go"

Duration 00:45:41,669 --> 00:45:43,762 
The slang words in data 8 show that slang is often also used intentionally to exclude other listeners who are outside a certain group of people, slang is used to prove that other people do not belong to a certain class. So, in this case, slang can indicate a person's identity related to social class and culture in society. Slang words can also only be understood by members between groups. This identity provides an understanding to the reader that social class can be formed from the use of variations in the language used.

Data 9.

Tuck : "Hey, yo Dj Sand! Drop that beat, homey. Looks like we've got new fish in town"

Dj Sand : "Let's clear the dance floor. See what they talking about"

Duration 00:45:51,849 --> 00:45:54,010

Fish means the stupid or incompetent person, this term is used by the speaker which denotes the speaker dislike or disrespect towards someone. This term turns out to be used to fight or challenge someone by using an impolite designation. In this context, someone is considered as a low person, because of different social status or different social culture of society.

That is the most relevant purpose of the use of slang used by the characters of the movie Step Up 2 The Street. Therefore, sometimes people use slang as a language to communicate with each other. Especially, having multiple goals such as being creative, fashionable, fun, different from the previous generation. One of the reasons for using slang is to enrich the language and to be able to interact among members of a group. Indicators to characterize social identities such as language, culture, race, religion, gender, political affiliation, colour and geographical region (Ngwenya, 2011).

Even in standup comics, they incorporate slang expressions into their routine, both as an expression of their social identity and to provoke laughter. How they convey their identity in their routine is an integral aspect of their stage persona. The slang expressions found in the analysis have been divided into four categories of social identity, namely: gender identity, ethnic identity, sexual orientation, and age (Larasati, 2018). Slang often affects the daily life of a group as a form of community social identities, such as in song or movie lyrics. Writers of songs or films usually include slang as a form of representation of their geographical area or the story they want to tell (Oktavia, 2017). Slang often affects the daily life of a group as a form of community social identities, such as in song or movie lyrics. The composers of songs or films usually include slang as a form of representation of their geographical area or the story they want to tell.

From the results of the analysis of the data findings in this film, it shows that today's young generation often adopts slang for communication from films, games, or social media as a form of embodiment of the existence of their social identity (Izazi \& Tengku-Sepora, 2020). There are even certain groups that can form a community and speak using slang that only the group can understand so that their social status or class becomes exclusive. This phenomenon is relevant to current conditions with changes in people's social life, knowledge and culture which have an impact on the development of language use. Slang is widely used by people from all walks of life. Even American slang was shaped and developed with American history. It has unique characteristics and functions. American slang reflects American culture. A sociolinguistic study of American slang helps people know more about American culture and society (Zhou \& Fan, 2013). Besides, students' linguistic, cultural, ethnic and social class backgrounds impact on their knowledge and experience of using academic language (Preece, 2015). Slang appears to be part of any language used in casual interaction by a community large enough and diverse enough to have identifiable subgroups. Furthermore, the structure of social identity is tied to the structure of society, so that as society 
grows larger and more interconnected, the landscape of social identity grows more heterogeneous (Smaldino, 2019)

\section{CONCLUSION}

The results of data analysis concluded that slang is considered the most powerful and expressive way to communicate because it is widely understood and in many cases, it is easier to prove something than using ordinary language. The findings of the data from the film Step Up 2 The Street show that social and cultural identities are focused on each status of a person and group. People who have higher status can use slang language to people who have lower status. In fact, the slang used often appears as an exclusive form of self or group based on culture, race, or social conditions of society. There are situations when slang is an effective way of expressing group and cultural identity.

The results of this analysis are still limited to the study of the context of slang in film literature through understanding the socio-cultural identity of speakers of that language. Therefore, this research can still be developed on aspects of real life that are happening today, especially among teenagers. Moreover, the impact of changes in global life that is increasingly widespread with advances in science and technology has a major impact on innovation and change or the birth of a new language. This limitation can be exploited by researchers in developing slang language research. This research is also expected to have implications for changing people's understanding of using slang to be more positive. Because so far, people who use slang are often associated with low socioeconomic status and low levels of education, slang has a place in communication.

\section{REFERENCES}

Budiana, N., \& Setiyoko, D. T. (2021). Students' Slang Language in WhatsApp on Effective Sentences: Sociolinguistics Review. International Journal of Multicultural and Multireligious Understanding, 8(1), 373-382. https://doi.org/10.18415/IJMMU.V8I1.2248

Budiasa, I. G., Savitri, P. W., \& Dewi, A. A. S. S. S. (2021). Slang Language in Indonesian Social Media. Lingual, 11(1), 30-34. https://doi.org/10.24843/LJLC.2021.V11.I01.P06

Hidayat, T. M., \& Mu'man, M. (2020). The word formation process of slang words in rich brian's song titled dat stick. PROJECT (Professional Journal of English Education), 3(4), 483. https://doi.org/10.22460/PROJECT.V3I4.P483-488

Istiqomah, L., Rohimah, A. N., \& Pratiwi, A. W. (2019). Slang Language Subtitle Strategy in the Movie Entitled "The Social Network." Langkawi: Journal of The Association for Arabic and English, 5(2), 152-162. https://doi.org/10.31332/LKW.V5I2.1298

Izazi, Z. Z., \& Tengku-Sepora, T. M. (2020). Slangs on Social Media: Variations among Malay Language Users on Twitter. Social Sciences \& Humanities2, 28(1), 17-34.

Kudirka, R. (2021). Suffixal Adjectives and Adjectival Participles in the Slang of Lithuanian Language. Respectus Philologicus, 40(40 (45)), 35-47. https://doi.org/10.15388/RESPECTUS.2021.40.45.90

Larasati, D. A. (2018). Slang as Social Identity in Stand-Up Comedy Academy Indosiar: A Sociolinguistics Study. International Journal of Languages, Literature and Linguistics, 4(3). https://doi.org/doi: 10.18178/ijll1.2018.4.3.179

Maxwell, J. A. (2013). Qualitative Research Design: An Interactive Approach. Third Ed. SAGE Publications, Inc.

Meinawati, E. (2017). Social dimension of slang word in film "Animal kingdom." Wanastra: Jurnal Bahasa Dan Sastra, 9(2), 156-166. https://doi.org/10.31294/w.v9i2.2583

Nasution, S. S., Karimah, L. J., Sitepu, S. S. W., Tryana, T., \& Kusumoriny, L. A. (2021). Slang 
Words in Me, and Earl, and The Dying Girl Novel: Type and Interpretation. Eralingua: Jurnal Pendidikan Bahasa Asing Dan Sastra, 5(1), 208-221. https://doi.org/10.26858/ERALINGUA.V5I1.14069

Ngwenya, T. (2011). Social identity and linguistic creativity: Manifestations of the use of multilingualism in South African advertising. Southern African Linguistics and Applied Language Studies, 29(1), 1-16. https://doi.org/10.2989/16073614.2011.583082

Oktavia, V. E. (2017). An analysis of slang words in the lyrics of far eas movement song as the form of language development and it's used in the daily life. The 1st Education and Language International Conference Proceedings, 899-904.

Preece, S. (2015). "They ain't using slang": Working class students from linguistic minority communities in higher education. Linguistics and Education, 31, 260-275. https://doi.org/10.1016/J.LINGED.2014.10.003

Sergienko, M. (2018). The Influence of the English Slang on the Modern Ukrainian Language. Traektoriâ Nauki, 4(12), 4006-4010. https://doi.org/10.22178/POS.41-6

Smaldino, P. E. (2019). Social identity and cooperation in cultural evolution. Behavioural Processes, 161, 108-116. https://doi.org/10.1016/J.BEPROC.2017.11.015

Zhou, Y., \& Fan, Y. (2013). A sociolinguistic study of American slang. Theory and Practice in Language Studies, 3(12), 2209-2213. https://doi.org/10.4304/TPLS.3.12.2209-2213 